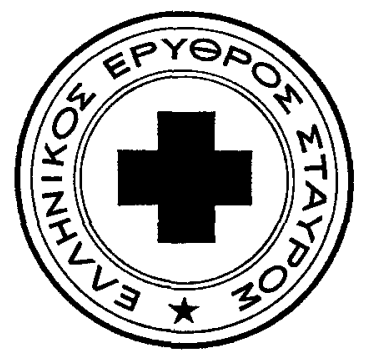

\title{
Centenary of the Hellenic Red Cross
}

Greece acceded to the first Geneva Convention of 22 August 1864 in January 1865. The Hellenic Red Cross Society was founded in 1877 , its foundation being approved by a royal decree dated 10 June 1877 ( 22 June 1877 according to the Julian calendar), and it was recognized by the International Committee of the Red Cross on 6 October that same year.

In its Circular No. 40 to the Central Committees for aid to wounded soldiers, the ICRC sent the following message, signed by its President G. Moynier, and its Secretary, G. Ador: "... today we take our pen to announce good tidings, and we are sure you will rejoice with us at the news that a Greek Society for aid to the wounded of armed forces in the field has recently been formed. Its creation is due to the initiative of H. M. the Queen of the Hellenes, who has graciously consented to place it under her high patronage, and its statutes have been formally approved by a royal decree dated 10/22 June 1977. The Society's Honorary President is the Metropolitan of Athens..." The President was the Governor of the Bank of Greece.

A ladies' auxiliary committee in Athens was founded at the same time and its President was the "First Lady-in-Waiting" of Her Majesty the Queen, “at the Court Athens".

The Hellenic Red Cross which was placed from the day of its foundation under the Queen's protection and which inherited an age-long tradition of fellowship towards all people in distress, enjoyed from its inception the support and backing of the entire Greek population. The Society developed steadily from 1877 onwards and its field of activity grew ever more extensively.

Here, for example, is an extract from the report ${ }^{1}$ on the Society's activities in 1898:

"... The Society continued its aid to the Thessalian refugees in Athens, Piraeus and Euboea, whom it treated as victims of the war, and

${ }^{1}$ Report published in the Bulletin international des Sociétés de la Croix-Rouge, 1901, pp. 99-104. 
who were still in deep distress and were suffering just as much from the dreadful insanitary conditions. Our association decided to continue supplying them with aid in the form of medical treatment, medicaments and basic necessities. From 1 January to 23 May 1898, it provided 17,348 okes of milk for the sick. It set up specially for the Thessalian refugees a dispensary which, in 1898, prepared 41,214 prescriptions issued by Red Cross doctors... Pharmacists and physicians vied with each other to render aid in a situation made still more distressing by the epidemics which broke out that winter in Athens. The worst cases were treated at the Kypseli Red Cross Hospital. The association also organized the general vaccination of all the refugees and supplied them with anti-diphtheria serum, beds, bedclothes, underwear, etc."

The Society moreover started to organize peace-time relief activities in the very earliest years of its existence and took part in international relief operations, as may be seen in its report ${ }^{1}$ for the years 1899 to 1901 :

"The Greek Red Cross, which considers it its duty to go to the aid of all the victims of disasters, gave relief during the last three years to needy smallpox patients in Athens, in Piraeus and in the village of Aprovato on Andros Island. It furnished equipment for the speedy set-up of a smallpox isolation hospital at Cantharos, near Piraeus, organized transport to evacuate smallpox patients fom Athens and Piraeus, and sent disinfectants to Aprovato.

"The association also sent the following relief supplies: underwear, clothing and bedclothes for the Greek refugees from the Caucasus in Piraeus; tents for the earthquake victims in Kyparissia; antiseptics, medicaments, dressings, wine, etc., to various benevolent institutions, such as the dispensary at Corfu, the Hermoupolis Hospital (Syra), the Yero-Limin Hospital and various hospitals in Athens (the Evanghelismos, the "Elpis" municipal hospital, the Areteion, the military hospital) and the Zannion in Piraeus.

"From the time when war broke out in South Africa, the Greek Red Cross, moved by the spirit of moral fellowship uniting all Red Cross associations to whatever country they might belong, wished to demonstrate its fellow feelings towards the wounded of the belligerent armies. In its desire to discharge its duty of international solidarity, it sent wine, brandy and cigarettes to the English Red Cross in London, the Transvaal Red Cross in Pretoria and the Orange Red Cross in Bloemfontein..."

1 Bulletin international des Sociétée de la Croix-Rouge, 1903, pp. 92-94. 
Today, after the latest revision of its statutes in 1965, the Hellenic Red Cross is administered by a Central Committee of 25 members, from amongst whom the executive committee members are elected. The Society's President is the chairman of the executive committee. There is a section of the Hellenic Red Cross in the capital of each "nomoi" (departments), and local committees have been set up in other towns. There are 82 active provincial sections.

The Society entertains excellent relations with the Greek Government, and meetings of the Hellenic Red Cross Committee are attended by representatives of five different ministries (Foreign Affairs, Education, National Defence, Finance and Social Welfare), who however are not entitled to vote. The Society's annual budget, which in the last few years has amounted to an average of one hundred million drachmae (about 250,000 US dollars), is covered by a substantial Government grant, an annual public collection campaign and contributions paid by the Society's members.

The public collection is countrywide and nurses, schoolchildren, boy scouts and other volunteers make door-to-door visits to collect donations. The campaign is generally a big success, which shows the affection which the inhabitants bear towards their National Red Cross Society.

During the past hundred years, Greece has experienced extremely turbulent and often tragic periods: two wars against Turkey, in 1897 and again in 1920-21, the Balkan Wars in 1912-13, two world wars, invasion and occupation by foreign troops, several national uprisings and serious internal disturbances, successive changes of régime ...there were few trials and difficulties from which it did not suffer at one time or another. The Hellenic Red Cross has always been active and ready on the spot in the course of its long history, endeavouring to bring relief to the many victims.

In such conditions, the Hellenic Red Cross considered it was of paramount importance, if it were to act swiftly and effectively in time of war, epidemic or natural disaster, that it should be able to count upon a medical service and upon nursing personnel in adequate numbers.

Today, over 12,000 nurses are enrolled in the Red Cross; 1,500 of them are registered nurses who have gone through a four-year course, while nearly 11,000 are nursing volunteers. In addition, in 1932 the Hellenic Red Cross began to train volunteer first aiders, who attend a course consisting of 128 lessons at the Red Cross First Aid School and complete their training in first-aid infirmaries. They number today about 2,500 persons. 
In time of war the Hellenic Red Cross was able, thanks to its medical and nursing personnel, to care for tens of thousands of wounded and sick in its permanent hospitals, field hospitals and hospital ships.

In peacetime, it offers its services to the Greek population. Besides its big general hospital in Athens, it set up, in 1923 in Voula (Attiki) some twenty kilometres outside Athens, an "Asclepeion", or hospital for patients suffering from tuberculosis of the bones. About twenty-five years ago, with the decline in the incidence of this disease, this Asclepeion was turned into a 750-bed orthopedic hospital.

Another Asclepeion, with 150 beds, is to be found on the Island of Leros. The Society owns three more general hospitals, each containing 30 to 45 beds, in Epirus, in the Peloponnessos and in the islands.

Blood transfusion was introduced and its service organized in Greece by the Hellenic Red Cross. From 1935, its Blood Transfusion Centre in Athens was able to meet the needs of the armed forces in time of war and of thousands of civilian patients in peacetime. The Centre has a research laboratory directed by eminent specialists. Blood transfusion services have also been set up in various other towns.

At the same time, the Society founded and organized, in Athens and elsewhere in the country, first-aid posts, where Red Cross ambulances are stationed ready at any time to take casualties and sick persons to hospital. It is estimated that approximately 200,000 trips of this kind are made every year by these vehicles. The Red Cross keeps fully equipped field hospitals, ready to be dispatched to the scene of epidemics or natural disasters.

The Hellenic Junior Red Cross was founded in 1924. During the Second World War it was disbanded, only to resume in 1946. It now counts half a million members belonging to 32,000 groups in schools throughout Greece, To lead and organize the activities of these groups, the Red Cross works in close co-operation with over 12,000 teachers, who instruct and help to propagate the ideals of the Red Cross. The National Society publishes a monthly periodical, called "The Hellenic Junior Red Cross", with a circulation of 300,000 copies. The Junior Red Cross is directed by a committee whose members belong to the Hellenic Red Cross and the Ministry for National Education, and its chairman is the President of the Red Cross Society.

In the summer of 1976, the Hellenic Red Cross opened a school for life-savers at sea. Within a few months, over 500 trainees followed the course and were awarded its diploma. At the same time, life-saving stations were attached to many of the first-aid posts referred to earlier to go to the aid of bathers in difficulty. 
Social welfare work receives attention, too. Health education and the protection of mother and child are prominent activities and a very large proportion of the population is reached, through nurses, voluntary workers and Junior Red Cross members. The Society also runs a health education centre in Athens and a rural health centre at Marathon.

Help for the sick, in hospital or at home, is provided by social workers and voluntary social welfare workers who also look after the aged and care for those who are in some way handicapped, whether physically, mentally or socially.

This organized structure of the Hellenic Red Cross enabled it, working in co-operation with the Athens Office of the High Commissioner for Refugees, to receive and accommodate about 2,800 refugees from Lebanon during 1976 and the earlier part of 1977. To do this, it mobilized 41 nurses and 15 doctors to care for the sick, the children and the social welfare cases among the refugees, who were all accommodated in Athens and its outskirts.

As regards information and public relations work, the Hellenic Red Cross does its utmost to kindle public interest in the ideals of the Red Cross, and to propagate the principles and aims of our movement. It is well served by the press, radio and television which willingly give the Society space and time. For example, they are always ready to report on the various important events which mark the Red Cross calendar: World Red Cross Day on 8 May, distributions of medals, presentations of diplomas, and so on.

A tracing service for missing persons is one of the departments of the Hellenic Red Cross. After the grave events of 1945-1947 endured by Greece, and on other occasions, too, the Hellenic Red Cross Tracing Service, in co-operation with the ICRC's Central Tracing Agency, managed to trace thousands of hostages and prisoners of war and return them to their families.

The Hellenic Red Cross and the ICRC have always worked very closely and actively together throughout the years in a spirit of great cordiality. It was during the Second World War and the months that immediately followed the end of the war that the work jointly performed 
by them both was most considerable and remarkable and a few pages taken from the Revue Internationale de la Croix-Rouge in 1944 and 1945 give a striking picture of the conditions in which that work was carried out: ${ }^{1}$

"The recent activities of the International Committee delegation in Athens were performed under very unusual and often dramatic conditions.

"The ICRC delegates in Greece pursued two different kinds of tasks. On the one hand, they discharged the specific duties incumbent upon the ICRC under the international Conventions of 1929; on the other hand, they distributed relief supplies to the civilian population and the hospital units in metropolitan Greece and the Greek Islands.

"The relief work accomplished was considerable; it should not be forgotten that for several years, ten, fifteen, and later nearly twenty thousand tons of foodstuffs arrived every month in the Port of Piraeus, to be unloaded, stored and the reloaded on lorries, caiques, goods wagons, and dispatched to various parts of the country for distribution. All means of communication were cut; bridges, railway lines, harbour installations had been rendered unfit for use, and none could say how long they would remain so. Civil war had broken out between the various political factions. The red cross sign was not everywhere respected and several times Red Cross lorries and the cars of delegates going about their mission were caught up in the firing.

"Sea transport involved great difficulties and was often fraught with danger. On its sixth voyage, in January 1942, the Turkish steamship "Kurtulus" ran aground in the Dardanelles and its precious cargo was lost. The "Stureborg" was torpedoed in the spring of 1942 and the ICRC agent on board was killed. Early in January 1943, the "Eros", carrying foodstuffs to Salonika, struck a reef and sank.

"To round off this brief survey, we would also mention that, from the time when this relief action for the Greek people was begun until October 1943 , more than 220,000 tons of wheat, about 6,250 tons of milk products equivalent to 13 million litres of milk, and 53,722 tons of various foodstuffs were distributed to the Greek inhabitants, thanks to the combined efforts of large numbers of willing volunteers.

"As regards the hostages, many attempts on both sides of the firing line were made, though in vain, to obtain their release. It was only on 5 January 1945 that the women, children and old people taken as hostages were released and the ICRC delegation obtained an official authorization to arrange for the return of those unfortunate people to Athens.

1 Revue Internationale de la Croix-Rouge, 1944, p. 18 et sq; id. 1945, p. 120 et sq. 
"The next thing to do was to set up a whole network to trace the hostages and organize communications between Lamia, south of Larissa, and Athens. The search for the 20,000 or so hostages, scattered in camps in mountainous areas, was rendered very arduous by the almost inaccessible regions in which some of the camps were located. The long, weary marches in wintry weather through deep snow were particularly distressing for the hostages, most of whom were underfed and in a state of utter destitution..."

The Hellenic Red Cross Society has managed to overcome the diffculties of the past and has stood up to seemingly crushing tasks. On the threshold of the second century of its existence, its friends express the wish that it may continue with the same courage and dedication which it has shown in the years gone by in its noble work and in times and circumstances which it is to be hoped will be less strenuous. 